\title{
The seven impediments in invertebrate conservation and how to overcome them
}

\author{
Pedro Cardoso $^{\mathrm{a}, \mathrm{b}, *}$, Terry L. Erwin ${ }^{\mathrm{a}}$, Paulo A.V. Borges ${ }^{\mathrm{b}}$, Tim R. New ${ }^{\mathrm{c}}$ \\ a Smithsonian Institution, National Museum of Natural History, 10th E Constitution NW, Washington, DC 20560, USA \\ ${ }^{\mathrm{b}}$ Azorean Biodiversity Group (CITA-A), Departamento de Ciências Agrárias, Universidade dos Açores, 9700-042 Angra do Heroísmo, Portugal \\ ${ }^{\mathrm{c}}$ Department of Zoology, La Trobe University, Bundoora, Victoria 3086, Australia
}

\section{A R T I C L E I N F O}

Article history:

Received 12 January 2011

Received in revised form 13 July 2011

Accepted 19 July 2011

Available online 12 August 2011

\section{Keywords:}

Conservation priorities

Ecosystem services

Extinction

Information shortfalls

Science funding

Species diversity

\begin{abstract}
A B S T R A C T
Despite their high diversity and importance for humankind, invertebrates are often neglected in biodiversity conservation policies. We identify seven impediments to their effective protection: (1) invertebrates and their ecological services are mostly unknown to the general public (the public dilemma); (2) policymakers and stakeholders are mostly unaware of invertebrate conservation problems (the political dilemma); (3) basic science on invertebrates is scarce and underfunded (the scientific dilemma); (4) most species are undescribed (the Linnean shortfall); (5) the distribution of described species is mostly unknown (the Wallacean shortfall); (6) the abundance of species and their changes in space and time are unknown (the Prestonian shortfall); (7) species ways of life and sensitivities to habitat change are largely unknown (the Hutchinsonian shortfall).

Numerous recent developments in taxonomy, inventorying, monitoring, data compilation, statistical analysis and science communication facilitate overcoming these impediments in both policy and practice. We suggest as possible solutions for the public dilemma: better public information and marketing. For the political dilemma: red-listing, legal priority listing and inclusion in environmental impact assessment studies. For the scientific dilemma: parataxonomy, citizen science programs and biodiversity informatics. For the Linnean shortfall: biodiversity surrogacy, increased support for taxonomy and advances in taxonomic publications. For the Wallacean shortfall: funding of inventories, compilation of data in public repositories and species distribution modeling. For the Prestonian shortfall: standardized protocols for inventorying and monitoring, widespread use of analogous protocols and increased support for natural history collections. For the Hutchinsonian shortfall: identifying good indicator taxa and studying extinction rates by indirect evidence.
\end{abstract}

(c) 2011 Elsevier Ltd. All rights reserved.

\section{The importance of invertebrates}

Invertebrates dominate among multicellular organisms in terms of richness, abundance and often biomass; for example, more than 100,000 species of terrestrial arthropods occupy a single hectare of rain forest in the western Amazon (Erwin et al., 2004) and there is more ant biomass in the soils of the Serengeti Plains than there is of surface mammals (Hölldobler and Wilson, 1990). About $80 \%$ of all described species are invertebrates. Beetles alone comprise at least 10 times the number of species of all vertebrates together and over $25 \%$ of all described species. Invertebrates may be as small as $30-40 \mu \mathrm{m}$ (male Cycliophorans, which have fewer than 60 cells on average (Neves et al., 2009)) or as large as $14 \mathrm{~m}$ (the colossal squid Mesonychoteuthis hamiltoni). They may be saprophagous, phytophagous, symbionts, parasites, endo and

* Corresponding author at: Azorean Biodiversity Group (CITA-A), Universidade dos Açores, Rua Capitão João d'Ávila, 9700-042 Angra do Heroísmo, Portugal. Tel.: +351295 402 200; fax: +351295402 205 .

E-mail address: pcardoso@ennor.org (P. Cardoso). ectoparasitoids, even hyper-parasitoids, or the top predators of a long chain. They may be cosmopolitan, or present in extremely restricted distributions of a few hectares (e.g. some cave adapted species). They live on land, in fresh water, and in all the oceans of the world. With such richness of species and roles in all ecosystems, preserving the diversity of invertebrates, as of all other organisms, is a true life insurance for humankind. As eloquently noted by Wilson (1987), "If human beings were to disappear tomorrow, the world would go on with little change. (...) But if invertebrates were to disappear, I doubt that the human species could last more than a few months".

The ways human beings benefit from the conservation of invertebrates are hard to quantify and the general public is often unaware of them. A study by Costanza et al. (2007) calculated that global ecosystem services are valued at US\$33 trillion per year, a large part of it directly or indirectly related with invertebrates. By 2050, biodiversity loss will be valued at $7 \%$ of the World's GDP (see: http://ec.europa.eu/environment/nature/biodiversity/ economics/teeb_en.htm). In the United States alone, and with a conservative and partial estimate, ecological services provided by 
insects annually were valued at US\$57 billion (Losey and Vaughan, 2006).

In order to reiterate the importance of ecosystems and their constituent species to humankind, ecosystem services have been divided in four broad categories by the Millennium Ecosystem Assessment (2003, 2005): provisioning, regulating, cultural, and supporting services.

\subsection{Provisioning services}

These are related with the goods that humans can use and trade. Besides being or providing food (e.g. molluscs, bees), invertebrates yield many new pharmaceuticals and compounds or processes useful for technological and industrial purposes (see: http:// www.wwf.org.au/publications/wwf-2010-and-beyond/), or may even be a target for mining activities (e.g. coral reefs).

\subsection{Regulating services}

These are related to the benefits of regulation of ecosystem processes provided by the different species. These services include pollination (e.g. of crop cultures), trophic regulation (e.g. pest control), or water purification (e.g. of ground waters by cave-obligate aquatic species).

\subsection{Cultural services}

These are non-material benefits. Invertebrates may serve as touristic attractions (e.g. coral reefs, butterflies), and many species are also essential model organisms for the study of biology, for example, the genetics of Drosophila and the many studies on increasing life-span performed with nematodes. In addition, many invertebrates are regularly used for environmental monitoring purposes (e.g. aquatic insects), as indicators of changes in the ecosystems that may not be felt as promptly in other taxonomic groups. Existence values are related with the willingness to pay for the conservation of species and communities (Martín-López et al., 2007). These are often prominent in flagship species, such as butterflies, dragonflies and corals, with which people may feel affinity or sympathy.

\subsection{Supporting services}

These are necessary for the production of all other ecosystem services and only indirectly impact on people's lives. Supporting services provided by invertebrates include nutrient cycling (e.g. dung burial, nitrogen volatilization), soil and ecosystem formation (e.g. aeration by tunneling, coral reefs) or as food source to other species (e.g. to commercial fisheries or game vertebrates).

\section{The neglect of invertebrates}

One of the major crises Earth's ecological stability faces today is the ever-growing and accelerating mass extinction of species due to human activities (Erwin, 1991a; Lawton and May, 1995; Purvis and Hector, 2000; Smith et al., 1993). Our knowledge of global biodiversity and its rate of extinction is very limited, but of the 3-100 million species believed to exist, conservative estimates point to about 3000 being lost each year, that is, eight species per day (Wilson, 2003a; González-Oreja, 2008). The vast majority belongs to understudied taxa such as certain groups of invertebrates, "the little things that run the world" (Evans, 1993; Wilson, 1987). They are subject to the same extinction processes as larger and more familiar organisms, plus a few additional ones, such as co-extinction and extinction of narrow habitat specialists (Dunn, 2005;
Dunn et al., 2009). When corrected for knowledge bias, data from invertebrates show even higher extinction rates and proportions of threatened species than those of well-known taxa such as birds and mammals (MacKinney, 1999; Moir et al., 2010; Stork and Lyal, 1993; Thomas and Morris, 1994). Nevertheless, only 70 species have been officially reported extinct for the last 600 years (Dunn, 2005), all others having vanished before discovery or description, the so-called Centinelan (Wilson, 1992) or Linnean extinctions (Cardoso et al., 2010; Ladle and Jepson, 2008; Régnier et al., 2009; Triantis et al., 2010).

The loss of species often implies the loss of functional diversity and the provision of ecosystem services, with consequences to human well-being (Section 1; see a review in Balvanera et al., 2006). The loss of pollinators may cause the loss of productivity in many crops (Kremen et al., 2002; Kremen and Ostfeld, 2005); the loss of predators and parasitoids in agricultural fields may cause the loss of ecosystem capacity to control pest outbreaks and the consequent loss in productivity (Landis et al., 2000; Symondson et al., 2002); the loss of groundwater fauna may cause the disruption of purification and bioremediation processes and consequent pollution problems (Boulton et al., 2008); the loss of coral reefs may cause diminishing returns from tourism (Moberg and Folke, 1999); among many other examples.

Despite their high diversity and importance for humankind, invertebrates have largely been neglected in conservation studies and policies worldwide (Cardoso et al., in press; Kremen et al., 1993; New, 1999; Zamin et al., 2010). Reflecting this neglect, the World Conservation Union's (IUCN) Red List of Threatened Species (IUCN, 2010) lists less than $0.5 \%$ of all described arthropods and $4 \%$ of all described molluscs worldwide (Fig. 1), when most vertebrates have already been assessed. Of all the species evaluated, the endangered categories occupy similar if not higher proportions than comparable numbers for vertebrates (Fig. 1). Even if such proportions are inflated by the evaluation of species thought $a$ priori to be endangered, the increases are countered by the vast numbers of undescribed species that mostly have restricted distributions and have not yet been collected or diagnosed (Gaston, 1994). National red lists follow the same trend, with invertebrates being among the taxa with the least comprehensive coverage in countries worldwide (Zamin et al., 2010).

Even in areas such as Europe where invertebrate species are relatively well known (Fig. 2a; Schuldt and Assmann, 2010), the support given to their conservation is markedly inappropriate considering their role in ecological processes upon which a healthy planet and human welfare depend (Leather, 2009). The largest funding program for the conservation of species and habitats in Europe is the LIFE-Nature program. Justification for funding is largely based on the priority lists of the Habitats and Birds Directives. Because such lists are markedly biased towards some well-known taxa, funding is equally biased (Fig. 2b; see also Cardoso, in press). On average, each arthropod species received 1000 times less funding for its conservation than each mammal species (Fig. 2c).

Contradicting the low level of conservation support given to invertebrates, when evaluated in equal stance to vertebrates, they rank high in conservation priority lists. In a recent resource allocation exercise for the Macaronesian archipelagos (Martín et al., 2010), using unbiased criteria to rank almost every insular taxon, invertebrates constituted more than twice the number of vertebrates among the highest ranking species. This was in a rank largely dominated by plants, which are also remarkably underrepresented in most conservation efforts (Figs. 1 and 2). In the Azores, where invertebrates have been thoroughly studied (Borges et al., 2005; Cardoso et al., 2007; Gaspar et al., 2008, in press; Triantis et al., 2010), more so than in the other archipelagos and most other regions worldwide, they constituted more than half of all priority species (Martín et al., 2010). 
(a)

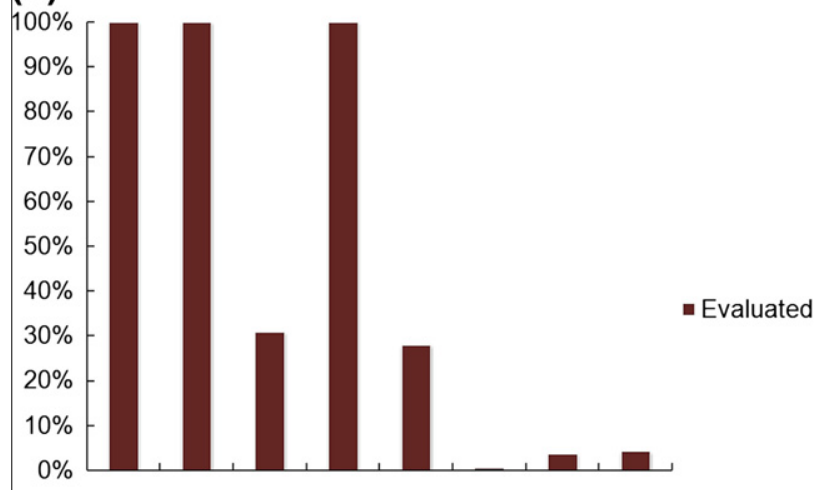

(b)

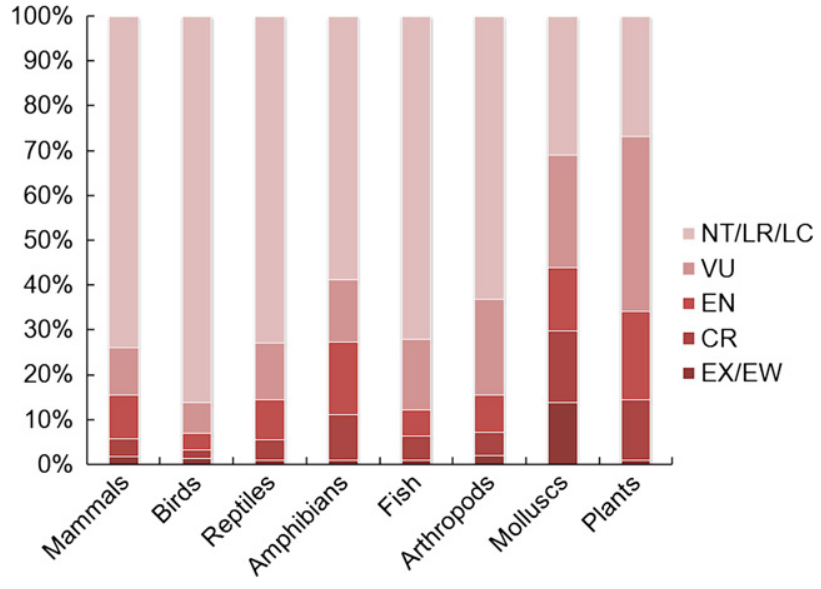

Fig. 1. Species included in the International Union for Conservation of Nature (IUCN) Red List: (a) proportion assessed from all known; (b) divided by threat category (NT - Near Threatened; LR - Lower Risk (only pre-2001 assessments); LC Least Concern; VU - Vulnerable; EN - Endangered; CR - Critically Endangered; EX Extinct; EW - Extinct in the Wild).

The data demonstrates that conservation priority lists are strongly biased towards some organisms. But why is there such a strong bias? We hereby propose a list of seven impediments to the conservation of invertebrates that are associated with such biases, and suggest some possibilities of how to overcome them (Table 1; Fig. 3; see also Kim, 1993; Samways, 1993). Three of the impediments are societal dilemmas, which interested parties face when deciding how important invertebrate conservation is. Four of the impediments are scientific shortfalls, related to areas of knowledge that are still far from sufficient and that sometimes reflect critical lack of data and understanding.

\section{The seven impediments and how to overcome them}

3.1. Invertebrates and their ecological services are mostly unknown to the general public (the public dilemma)

Invertebrate conservation is hard to justify when many people see each insect as a potential pest or each spider as a potential health threat (Martín-López et al., 2007). With a few exceptions (e.g. bees, butterflies), the public is not aware of invertebrate roles in ecosystems and the conservation threats many species are facing. Without such information, people tend to disregard invertebrates as important for ecosystem functioning or as in need of protection (Martín-López et al., 2007; Samways, 1993). Public support is fundamental in reducing the current extinction rates (Ladle and Jepson, 2008). (a)

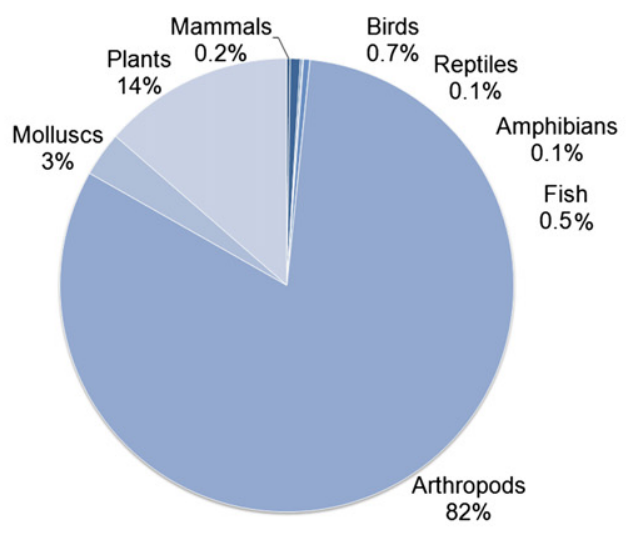

(b)

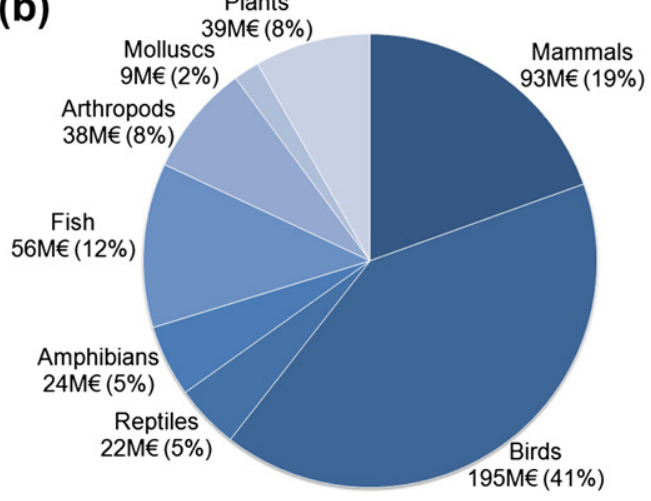

(c)

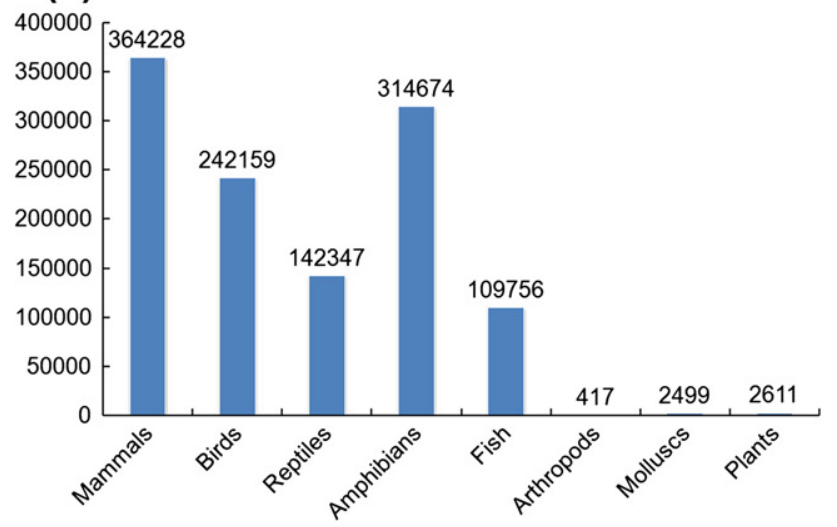

Fig. 2. European species and support given by the EU LIFE-Nature program: (a) proportion of known species richness per taxon; (b) total funding provided per taxon; (c) average funding provided per species (in Euros).

On the other hand, with information available and when blindly questioned about what species attributes are more important for defining priorities, the public ranks endemism or uniqueness to a region as the most important (Meuser et al., 2009). Invertebrates usually comprise most endemics in a region. If the public is made aware of the importance of invertebrates in ecosystem functioning and other benefits, direct or indirect to humans, perceptions are also likely to change. Knowing how to "sell" whatever knowledge and reasoned inference is available is essential in every area, including invertebrate conservation, and greater public awareness is likely to increase support for conservation (Meuser et al., 2009; New, 2010; Tisdell and Wilson, 2006; Wilson and Tisdell, 2005). News regarding species discovery, wildlife documentaries, photography books or exhibitions and the arts in general all are effective tools in changing public perceptions, enhancing ability 
Table 1

The seven impediments in invertebrate conservation and how to overcome them.

\begin{tabular}{|c|}
\hline Impediments \\
\hline $\begin{array}{l}\text { I. Public dilemma - people throughout the world do not recognize invertebrates or their roles in the } \\
\text { ecosystem. In consequence, the public has the tendency to disregard invertebrate species as in need } \\
\text { of protection }\end{array}$ \\
\hline $\begin{array}{l}\text { II. Political dilemma - many policymakers and stakeholders see invertebrates as species that, if needed, } \\
\text { are indirectly protected by "umbrella" vertebrate species. In consequence, protection measures and } \\
\text { funding are limited }\end{array}$ \\
\hline $\begin{array}{l}\text { III. Scientific dilemma - the discovery and description of new species and the collecting of spatial and } \\
\text { temporal data on known species are increasingly regarded as dated science. In consequence, } \\
\text { taxonomy and classical ecology are underfunded }\end{array}$ \\
\hline $\begin{array}{l}\text { IV. Linnean shortfall - the knowledge of the identity of species on Earth is remarkably poor, with many } \\
\text { species yet to be described and catalogued. The term is a reference to the scientist Carl Linnaeus } \\
(1707-1778) \text {, who laid the foundations of modern taxonomy in the 18th century }\end{array}$ \\
\hline $\begin{array}{l}\text { V. Wallacean shortfall - refers to our inadequate knowledge of the distributions of species at all } \\
\text { possible scales. This term is a reference to Alfred R. Wallace (1823-1913), who studied the patterns } \\
\text { and processes in the geographical distribution of species }\end{array}$ \\
\hline $\begin{array}{l}\text { VI. Prestonian shortfall - comparative species abundance data in space and time is usually scarce. The } \\
\text { term is a reference to the work by Frank W. Preston (1896-1989) on the commonness and rarity of } \\
\text { species and their changes in space and time }\end{array}$ \\
\hline $\begin{array}{l}\text { VII. Hutchinsonian shortfall - the diverse ways of life, functional roles and consequently the sensitivity } \\
\text { to habitat change of most species are usually unknown. This term is a reference to the work by } \\
\text { George E. Hutchinson (1903-1991) on the niche concept and the way resources limit the } \\
\text { distribution and abundance of species }\end{array}$ \\
\hline
\end{tabular}
Possible solutions

(a) Better information

(b) Better marketing

(a) Red-listing

(b) Legal priority listing

(c) Inclusion in environmental impact assessment studies

(a) Parataxonomy

(b) Citizen science programs

(c) Biodiversity informatics

(a) Biodiversity surrogacy

(b) Increased support for taxonomy

(c) Advances in taxonomic publication processes

(a) Funding of regional or worldwide inventories

(b) Compilation of primary biodiversity data in public repositories

(c) Species distribution modeling

(a) Standardization and optimization of sampling protocols developed for inventorying and monitoring

(b) Adoption of analogous protocols by different teams

(c) Increased support for natural history collections

(a) Identifying good indicator taxa that respond rapidly to ecological change

(b) Studying extinction rates by indirect evidence

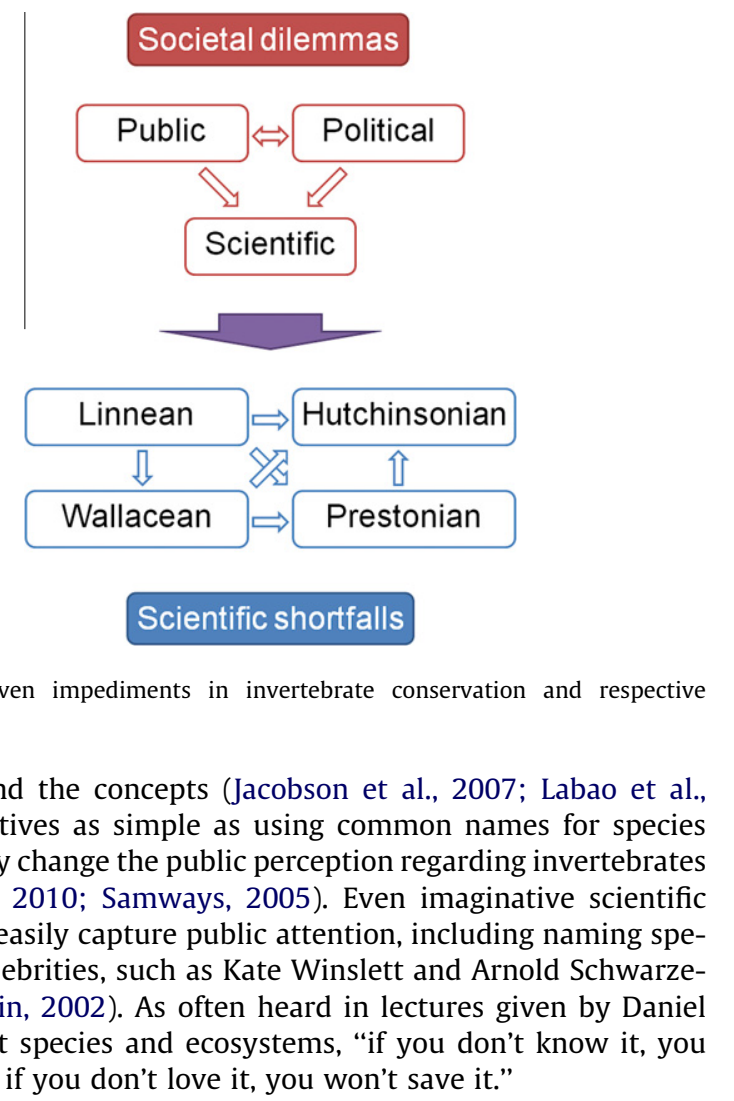

\subsection{Policymakers and stakeholders are mostly unaware of invertebrate conservation problems (the political dilemma)}

Policymakers and stakeholders usually assume that protected large animals will serve as "umbrella" species, protecting all other species occupying the same habitats (Simberloff, 1998). This view is however largely unsupported and untested. In the vast majority of cases it is simply assumed (Cabeza et al., 2008; Muñoz, 2007; Prendergast et al., 1993; Roth and Weber, 2008; Simberloff, 1998). When tested, the concept often fails (Martín et al., 2010; Schuldt and Assmann, 2010). Indeed, our lack of knowledge may preclude investigation of any such relationships for most invertebrate groups, because the questions cannot be framed. Misconceptions regarding the effectiveness of umbrella species have been detrimental to possible invertebrate conservation, by limiting the amount of available funding.

As with the general public, information regarding the importance of invertebrates in ecosystem functioning may be very effective in explaining the value of less charismatic species to policymakers and stakeholders. Without legal value but with political significance, mechanisms such as the IUCN Red List are powerful tools for lobbying and this use should increase (Mace et al., 2008; Rodrigues et al., 2006). Many invertebrate taxa have recently been assessed, especially molluscs, butterflies, dragonflies, freshwater crabs, and corals (Clausnitzer et al., 2009; Cumberlidge et al., 2009; IUCN, 2010; Lewis and Senior, 2011). There are also many regional studies already published (e.g. butterflies and dragonflies in Europe) (Kalkman et al., 2010; Van Swaay et al., 2010, 2011). After red-listing, it may be easier to include a species in conservation priority lists with legal support. Legally binding lists can't love it, if you don't love it, you won't save it." 
should include more species, chosen according to objective parameters applicable to all organisms (Martín et al., 2010). Finally, environmental impact assessment studies should not be limited to abundant, non-threatened organisms, which are often widespread. These three measures (red-listing, legal priority listing and inclusion in environmental impact assessment studies) would force stakeholders to include invertebrates in their plans and the knowledge regarding each putatively threatened invertebrate species could rapidly increase without public expenditure.

\subsection{Basic science on invertebrates is scarce and underfunded (the scientific dilemma)}

Traditional taxonomy is on the verge of extinction, facing ever scarcer resources, and mostly regarded as "counting for the sake of counting", with "modern" sciences occupying taxonomy's former space (Boero, 2001, 2010; Leather and Quicke, 2009; Wheeler, 2007). Taxonomists are moving towards other fields and many of those remaining, besides approaching retirement, are based in countries where most species are already known (Gaston and May, 1992; Kim, 1993). Natural history and ecological studies, based on broad sampling programs that allow knowing the species distributions and abundances, how such parameters change in space and time and how these changes relate with ecological change are also largely neglected (Cotterill and Foissner, 2010; Kim, 1993).

A number of partial solutions are in effect to counter the lack of experienced taxonomists, even if modern taxonomy is more concerned with resolving high-level phylogenies using molecular techniques that require specialized skills and equipment, than with basic species descriptions and diagnoses. Especially in the tropics, parataxonomists with training that allows them to recognize and sort morphospecies are often used with success (Basset et al., 2004; Janzen, 2004; Pearson et al., 2011). Amateurs are frequently the most proficient descriptors of species in many taxa (Pearson et al., 2011) and, often integrated in citizen science programs, also provide extremely useful data on the distribution and abundance of species (Braschler, 2009; Cohn, 2008; Silverton, 2009). Given the high costs of obtaining comparative taxonomic and ecological information, cybertaxonomy (Table 2; Wheeler, 2004, 2007; Wheeler et al., 2004), and the field of biodiversity informatics in general allow the efficient and universal access to species lists, distribution databases and ecological data. Biodiversity informatics facilitates species identification and access to a wealth of information (Borges et al., 2010; Wilson, 2000, 2003b).

\subsection{Most species are undescribed (the Linnean shortfall)}

Most living species are still to be described (Erwin et al., 2004; May, 1999). This problem is especially prevalent in invertebrates, with researchers still far from agreeing on the possible number of species, estimated to be anywhere between 3 and 50 million, with the most probable estimates between 5 and 30 million (Erwin et al., 2004; Wilson, 2000; but see Novotny et al., 2002). When more than one order of magnitude separates different global richness estimates, the size of this so-called "Linnean shortfall" becomes obvious (Brown and Lomolino, 1998). In fact, the number of new species described every year is not approaching an asymptote. About 15,000 new species and sub-species of invertebrates are recorded by Zoological Record each year (see: http://www.organ ismnames.com). This represents one new taxon (mostly species) described every $35 \mathrm{~min}$. And yet, at the present rate of description, and even by the most conservative estimates claiming that half the species have already been described, it could take close to 100 years to reach the end of the process. Hundreds of thousands of species may become extinct before description (González-Oreja, 2008).

Surrogacy, either by higher taxa (Gaston and Williams, 1993) or by indicator taxa (Pearson and Cassola, 1992), can be an efficient way of obtaining useful information for conservation without the need to identify every single species. This strategy allows the retention of broad biological information enabling the understanding of distribution patterns and efficiency in the definition of conservation priority areas. Its use is, however, necessarily limited and for most conservation questions it is in fact important to know the species identity. The resolution of this impediment ultimately depends on the resolution of others, predominantly, the lack of taxonomists and the wider recognition by policymakers that to conserve biodiversity it may be important to know what biodiversity is present. Knowledge allows wise decisions and should guide priorities for best use of very restricted resources available for practical conservation. Importantly, new projects have appeared funded by the US National Science Foundation, such as the Partnerships to Enhance Expertise in Taxonomy (PEET), Assembling the Tree of Life (AToL), and the Planetary Biodiversity Inventory (PBI) and the Smithsonian Institution, such as the currently developing Global Genome Project. In Europe, the EDIT project is a good example of taxonomy enhancement. In addition, new advances in taxonomic publication processes are designed to speed species information automatically to diverse users (Penev et al., 2008, 2011).

\subsection{The distribution of described species is mostly unknown (the Wallacean shortfall)}

Most species remain undescribed and unknown. Recognizing and describing them is, however, just the beginning of a process. For most of the species already described, we probably know little more than some morphological characteristics and a few, if not a single, locality (as a spot distribution within an unknown range). This shortfall was named by Lomolino (2004) as the "Wallacean shortfall". Compiling good distributional data is the first stage of any systematic conservation planning exercise (Margules and Pressey, 2000). Without reasonable information of where species live, it is impossible to know which are endangered and where to concentrate efforts to preserve them.

Table 2

Examples of cybertaxonomy projects.

\begin{tabular}{|c|c|c|c|}
\hline Name & Target taxa & Geographical extent & URL \\
\hline DELTA & Several & World & http://delta-intkey.com/www/data.htm \\
\hline EUTAXA & Several & Europe & http://www.eutaxa.com/ \\
\hline Ground beetles of Ireland & Carabidae & Ireland & http://www.habitas.org.uk/groundbeetles/index.html \\
\hline National Barkfly Recording Scheme & Psocoptera & United Kingdom & http://www.brc.ac.uk/schemes/barkfly/homepage.htm \\
\hline NatureGate & Several & Finland & http://www.luontoportti.com/suomi/en/ \\
\hline Spiders of Europe & Araneae & Gaspar Europe & http://www.araneae.unibe.ch/ \\
\hline UK Butterflies & Lepidoptera & United Kingdom & http://www.ukbutterflies.co.uk/ \\
\hline UK Moths & Lepidoptera & United Kingdom & http://www.ukmoths.org.uk/ \\
\hline Universal Chalcidoidea Database & Hymenoptera & World & http://www.nhm.ac.uk/research-curation/research/projects/chalcidoids/keys1_14.htm \\
\hline
\end{tabular}


Table 3

Examples of large-scale sampling initiatives.

\begin{tabular}{|c|c|c|c|}
\hline Name & Target taxa & Geographical extent & URL or reference \\
\hline $\begin{array}{l}\text { Arthropod Initiative of the Smithsonian } \\
\text { Center for Tropical Forest Science }\end{array}$ & Several & Tropics & http://www.ctfs.si.edu/group/arthropodmonitoring \\
\hline BALA & Arthropods & Azores & Borges et al. (2005), Cardoso et al. (2007), and Gaspar et al. (2008, in press) \\
\hline COBRA & Spiders & Worldwide & Cardoso (2009) and Cardoso et al. (in preparation) \\
\hline ALL & Ants & Tropics & Agosti and Alonso (2000) \\
\hline TEAM & Several & Tropics & http://www.teamnetwork.org/en/ \\
\hline RAP & Several & Worldwide & https://learning.conservation.org/biosurvey/RAP/Pages/default.aspx \\
\hline Pollard and Yates & Butterflies & Worldwide & Pollard and Yates (1993) \\
\hline
\end{tabular}

A suggestion for overcoming the Wallacean shortfall implies the recognition that there is need to enhance the funding of traditional local and regional inventories, if possible using adequate standardized and optimized protocols (see below). Nonetheless, such data need to be readily available. Different initiatives compile distribution data of diverse taxa from local to global levels, most remarkably, the GBIF - Global Biodiversity Information Facility (http:// www.gbif.org). It intends to compile in a single platform all data, especially primary data, stored in thousands of museums worldwide. But even compiling all available information this will be scattered and probably biased for most taxa (Hortal et al., 2007), with documented distribution tending to be that of interested specialists and where they have collected. Several species distribution modeling techniques have therefore been proposed to fill the gaps in information (Elith et al., 2006; Hernández et al., 2006; Phillips et al., 2006). These allow mapping the probabilities of occurrence for species for which only some records are available by evaluating what climatic, land-use or other variables are suitable for the occurrence of the species. Such probabilities of occurrence can be used in conservation planning (Cabeza et al., 2010; Williams and Araújo, 2000) together with a number of other variables, such as management costs and prevalence of threats. Although such distribution models may present several problems, often not taking into account the way of life and history of taxa, species interactions or the possibly biased geographical sampling (Soberón and Nakamura, 2009), they can be seen as a way of reducing the unavoidable bias of using data from only a few scattered places for conservation planning (Diniz-Filho et al., 2010).

\subsection{The abundance of species and their changes in space and time are unknown (the Prestonian shortfall)}

Absolute abundances of invertebrates are usually impossible to obtain and too variable to measure. Hence, we have to trust on relative abundance. This can be compared in space (through inventorying) and time (through monitoring), both processes presuming we can recognize and categorize the entities we measure. Studying such variables requires standardized and optimized sampling protocols (Cardoso, 2009; Duelli, 1997; Duelli et al., 1999; Erwin, 1991b; Jones and Eggleton, 2000; Régnier et al., 2009; Stork et al., 1996). Researchers involved in invertebrate sampling, however, usually do not immediately extract all information possible to obtain from the specimens collected. Those data vanish in time, with specimens being forgotten or even lost in privately-run collections, even in universities. The collected material is therefore not usable to its full potential. Given the work by Frank W. Preston on the commonness and rarity of species and their changes in space and time (Preston, 1948, 1960) we refer to this impediment as the "Prestonian shortfall".

Improvement of sampling and analytical methods for biodiversity assessment and monitoring has been identified as an important priority in insect conservation and diversity research (Didham et al., 2010; Kim, 1993). Standard protocols have been proposed for large-scale or even global comparative inventories (Table 3) of different taxa such as ants (Agosti and Alonso, 2000) and butterflies (Pollard and Yates, 1993). Based on a semiquantitative sampling strategy first proposed by Coddington et al. (1991), Cardoso (2009) proposed guidelines and statistical methods to improve the standardization and optimization of arthropod inventories, and demonstrated that it is possible to sample in a standardized, yet optimized, way. The use of standardized and optimized protocols, well-supported by extensive data, may contribute to the more rapid accumulation of knowledge in ways that allow using all the information to its full potential, for a number of different studies (Diniz-Filho et al., 2010; Kremen et al., 1993). There is also a need for long term ecological studies to monitor ecosystem change through time and such studies also require standardized and optimized protocols for good indicator invertebrate taxa. The new NSF-funded program NEON is beginning to piece together the protocols for exactly this strategy. Preserving all possible information for future studies, often impossible to predict, is possible only if specimens are maintained as long-term, secure, archive collections with full documentation. This preservation is best accomplished through the support of natural history collections, namely in museums, which constitute rich sources of long-term datasets (Cotterill and Foissner, 2010; Lister et al., 2011).

\subsection{Species ways of life and sensitivities to habitat change are largely unknown (the Hutchinsonian shortfall)}

In addition to grossly inadequate taxonomic, distributional and abundance knowledge, the very diverse ways of life (autecological aspects) and the ecosystem services associated with the different species are usually unknown. This impediment was named by Mokany and Ferrier (2011) as the "Hutchinsonian shortfall". Not knowing what species contribute to what ecosystem services means that the full consequences of species extinctions are extremely hard to predict. Complementary information, such as sensitivity to ecological change driven by anthropogenic causes, is known only for a limited number of species (Kozlowski, 2008). Even in the best-documented faunas the threats to most individual species can be suggested in only general terms, often drawing on knowledge of biologically different but related species elsewhere.

Our knowledge is however steadily growing. Many invertebrate species are now known to be sensitive to ecological change (e.g. Basset et al., 2008; Cardoso et al., 2007) and when sufficient data is available it is even possible to infer on the past (Cardoso et al., 2010) or future (Fonseca, 2009; Triantis et al., 2010) man-caused extinctions of numerous species. Moreover, many invertebrates are susceptible to extinction causes that mostly do not occur in better-known taxa, such as extreme habitat specificity and coextinctions along with hosts (Dunn, 2005; Dunn et al., 2009). Indeed, coextinction may be the most common form of extinction (Dunn et al., 2009; Moir et al., 2010). Although the ecology and sensitivity to habitat change of most species is unknown, many studies indicate that invertebrates can be as sensitive as any other 
taxa (MacKinney, 1999). Given their variety of species, sizes and functional roles, with short generation times, rapid evolutionary rates and often marked habitat fidelity, many invertebrate taxa are indeed ideal indicators of habitat change caused by human activity, more so than vertebrates, providing datasets with higher temporal and spatial resolution for conservation (Diniz-Filho et al., 2010; Gaspar et al., in press; Kremen et al., 1993).

\section{Conclusions}

We have outlined seven topics that we regard as impediments that hamper progress in the conservation of invertebrate species at a global level. These impediments represent only one of the several possible ways of dividing the problems related to invertebrate conservation. Nevertheless, we think that the present division is constructive. It is the public and politicians who ultimately decide which science is worth supporting at each moment. The Linnean shortfall is the obvious basis for the other scientific shortfalls (Fig. 3). The Wallacean, Prestonian and Hutchinsonian shortfalls have parallels with the three basic forms of rarity, by respectively relating with distribution, abundance and habitat (Gaston, 1994; Rabinowitz, 1981).

We also list possible ways of overcoming such impediments and they are therefore not intractable. In fact, we mention a number of initiatives, not in any way comprehensively, that indicate progress. At least in developed countries it should be easy to incorporate effective invertebrate conservation in environmental policies in full parallel to other taxa. In underdeveloped countries, where most invertebrate diversity resides, all these problems are far greater. Funding and appropriate environmental policies are lacking even for charismatic taxa. Nevertheless, all the tools developed for countries where the problem seems easier to resolve are or will certainly be useful at a global level and, if mastered, will be available in the future.

Finally, it must be highlighted that invertebrate conservation, as well as of all biodiversity, is only possible with the preservation of ecosystems and their structure, function and processes (Kim, 1993; Samways, 1993). Describing and understanding the roles and ecosystem services provided by different species could help linking invertebrate conservation with human well-being. This link is critical for increasing the public, political and even scientific support for invertebrate conservation. Single-species management is useful in a limited sense only, as all species are interconnected in ways we are just beginning to understand. Only by preserving all species and guaranteeing interactions and ecosystem services may we reach the goal of overall biodiversity conservation.

\section{Acknowledgements}

We thank J. Hortal, S. Ribeiro and A.S. Pullin for suggestions and fruitful discussions around the subject. P.C. and P.A.V.B. are supported by the Portuguese Foundation for Science and Technology (SFRH/BPD/40688/2007; FCT - PTDC/BIA-BEC/104571/2008; FCT - PTDC/BIA-BEC/100182/2008).

\section{References}

Agosti, D., Alonso, L.E., 2000. The ALL protocol - a standard protocol for the collection of ground-dwelling ants. In: Agosti, D., Majer, J.D., Alonso, L.E., Schultz, T.R. (Eds.), Ants - Standard Methods for Measuring and Monitoring Biodiversity, Biological Diversity Handbook Series. Smithsonian Institution Press, Washington, DC, pp. 204-206.

Balvanera, P., Pfisterer, A.B., Buchmann, N., He, J.-S., Nakashizuka, T., Raffaelli, D., Schmid, B., 2006. Quantifying the evidence for biodiversity effects on ecosystem function and services. Ecology Letters 9, 1146-1156.

Basset, Y., Novotny, V., Miller, S.E., Weiblen, G.D., Missa, O., Stewart, A.J.A., 2004. Conservation and biological monitoring of tropical forests: the role of parataxonomists. Journal of Applied Ecology 41, 163-174.
Basset, Y., Missa, O., Alonso, A., Miller, S.E., Curletti, G., De Meyer, M., Eardley, C., Lewis, O.T., Mansell, M.W., Novotny, V., Wagner, T., 2008. Choice of metrics for studying arthropod responses to habitat disturbance: one example from Gabon. Insect Conservation and Diversity 1, 55-66.

Boero, F., 2001. Light after dark: the partnership for enhancing expertise in taxonomy. Trends in Ecology and Evolution 16, 266.

Boero, F., 2010. The study of species in the era of biodiversity: a tale of stupidity. Diversity 2, 115-126.

Borges, P.A.V., Aguiar, C., Amaral, J., Amorim, I.R., André, G., Arraiol, A., Baz, A., Dinis, F., Enghoff, H., Gaspar, C., Ilharco, F., Mahnert, V., Melo, C., Pereira, F., Quartau, J.A., Ribeiro, S., Ribes, J., Serrano, A.R.M., Sousa, A.B., Strassen, R.Z., Vieira, L., Vieira, V., Vitorino, A., Wunderlich, J., 2005. Ranking protected areas in the Azores using standardized sampling of soil epigean arthropods. Biodiversity and Conservation 14, 2029-2060.

Borges, P.A.V., Gabriel, R., Arroz, A., Costa, A., Cunha, R., Silva, L., Mendonça, E., Martins, A.F., Reis, F., Cardoso, P., 2010. The Azorean Biodiversity Portal: an internet database for regional biodiversity outreach. Systematics and Biodiversity 8, 423-434.

Boulton, A.J., Fenwick, G.D., Hancock, P.J., Harvey, M.S., 2008. Biodiversity, functional roles and ecosystem services of groundwater invertebrates. Invertebrate Systematics 22, 103-116.

Braschler, B., 2009. Successfully implementing a citizen-scientist approach to insect monitoring in a resource-poor country. Bioscience 59, 103-104.

Brown, J.H., Lomolino, M.V., 1998. Biogeography. Sinauer Press, Sunderland, Massachusetts.

Cabeza, M., Arponen, A., Van Teeffelen, A., 2008. Top predators: hot or not? A call for systematic assessment of biodiversity surrogates. Journal of Applied Ecology 45, 976-980.

Cabeza, M., Arponen, A., Jäättelä, L., Kujala, H., Van Teeffelen, A., Hanski, I., 2010. Conservation planning with insects at three different spatial scales. Ecography 33, 54-63.

Cardoso, P., 2009. Standardization and optimization of arthropod inventories - the case of Iberian spiders. Biodiversity and Conservation 18, 3949-3962.

Cardoso, P., in press. Habitats directive species lists: urgent need of revision. Insect Conservation and Diversity. doi:10.1111/j.1752-4598.2011.00140.x.

Cardoso, P., Borges, P.A.V., Gaspar, C., 2007. Biotic integrity of the arthropod communities in the natural forests of Azores. Biodiversity and Conservation 16, 2883-2901.

Cardoso, P., Arnedo, M.A., Triantis, K.A., Borges, P.A.V., 2010. Drivers of diversity in Macaronesian spiders and the role of species extinctions. Journal of Biogeography 37, 1034-1046.

Cardoso, P., Borges, P.A.V., Triantis, K.A., Ferrández, M.A., Martín, J.L., in press. Adapting the IUCN red listing criteria for invertebrates. Biological Conservation. doi:10.1016/j.biocon.2011.06.020.

Cardoso, P., Scharff, N., Coddington, J.A., in preparation. Inventorying and estimating spider biodiversity in tropical forests.

Coddington, J.A., Griswold, C.E., Silva-Dávila, D., Peñaranda, E., Larcher, S.F., 1991. Designing and testing sampling protocols to estimate biodiversity in tropical ecosystems. In: Dudley, E.C. (Ed.), The Unity of Evolutionary Biology: Proceedings of the Fourth International Congress of Systematic and Evolutionary Biology. Dioscorides Press, Portland, pp. 44-60.

Cohn, J.P., 2008. Citizen science: can volunteers do real research? Bioscience 58, 192-197.

Costanza, R., d’Arge, R., de Groot, R.S., Farber, S., Grasso, M., Hannon, B., Limburg, K., Naeem, S., O'Neill, R.V., Paruelo, J., Raskin, R.G., Sutton, P., van den Belt, M., 2007. The value of the world's ecosystem services and natural capital. Nature 387, 253-260.

Cotterill, F.P.D., Foissner, W., 2010. A pervasive denigration of natural history misconstrues how biodiversity inventories and taxonomy underpin scientific knowledge. Biodiversity and Conservation 19, 291-303.

Clausnitzer, V., Kalkman, V.J., Ram, M., Collen, B., Baillie, J.E.M., Bedjanic, M., Darwall, W.R.T., Dijkstra, K.B., Dow, R., Hawking, J., Karube, H., Malikova, E., Paulson, D., Schütte, K., Suhling, F., Villanuevam, R.J., Ellenrieder, N., Wilson, K., 2009. Odonata enter the biodiversity crisis debate: the first global assessment of an insect group. Biological Conservation 142, 1864-1869.

Cumberlidge, N., Ng, P.K., Yeo, D.C.J., Magalhaes, C., Campos, M.R., Alvarez, F., Naruse, T., Daniel, S.R., Esser, L.J., Attipoe, F.Y.K., Clotilde-Ba, F.-L., Darwall, W., Mcivor, A., Ram, M., Baillie, J.E.M., Collen, B., 2009. Freshwater crabs and the biodiversity crisis: importance, threats, status, and conservation challenges. Biological Conservation 142, 1665-1673.

Didham, R.K., Basset, Y., Leather, S.R., 2010. Research needs in insect conservation and diversity. Insect Conservation and Diversity 3, 1-4.

Diniz-Filho, J.A.F., Marco, P., Hawkins, B.A., 2010. Defying the curse of ignorance: perspectives in insect macroecology and conservation biogeography. Insect Conservation and Diversity 3, 172-179.

Duelli, P., 1997. Biodiversity evaluation in agricultural landscapes: an approach at two different scales. Agriculture, Ecosystems and Environment 62, 81-91.

Duelli, P., Obrist, M.K., Schmatz, D.R., 1999. Biodiversity evaluation in agricultural landscapes: above-ground insects. Agriculture, Ecosystems and Environment $74,33-64$.

Dunn, R.R., 2005. Modern insect extinctions, the neglected majority. Conservation Biology 19, 1030-1036.

Dunn, R.R., Harris, N.C., Colwell, R.K., Koh, L.P., Sodhi, N.S., 2009. The sixth mass coextinction: are most endangered species parasites and mutualists? Proceedings of the Royal Society B 276, 3037-3045. 
Elith, J., Graham, C.H., Anderson, R.P., Dudik, M., Ferrier, S., Guisan, A., Hijmans, R.J., Huettmann, F., Leathwick, J.R., Lehman, A., Li, J., Lohman, L.G., Loiselle, B.A., Manion, G., Moritz, C., Nakamura, M., Nakazawa, Y., Overton, J.M.C., Peterson, A.T., Philips, S.J., Richardson, K., Scachetti-Pereira, R., Schapire, R.E., Soberón, J., Williams, S., Wisz, M.S., Zimmermann, N.E., 2006. Novel methods improve prediction of species' distributions from occurrence data. Ecography 29, 129151

Erwin, T.L., 1991a. An evolutionary basis for conservation strategies. Science 253, 750-752.

Erwin, T.L., 1991b. Establishing a tropical species co-occurrence database. Part 1. A plan for developing consistent biotic inventories in temperate and tropical habitats. Memoria del Museo de Historia Natural 20, 1-16.

Erwin, T.L., 2002. The beetle family Carabidae of Costa Rica: twenty-nine new species of Costa Rican Agra Fabricius 1801 (Coleoptera: Carabidae, Lebiini, Agrina). Zootaxa 119, 1-68.

Erwin, T.L., Pimienta, M.C., Murillo, O.E., Aschero, V., 2004. Mapping patterns of $\beta$ diversity for beetles across the western Amazon Basin: a preliminary case for improving conservation strategies. Proceedings of the California Academy of Sciences $56,72-85$.

Evans, H.E., 1993. Life on a Little-Known Planet: A Biologist's View of Insects and their World. Lyons and Burford, NY.

Fonseca, C.R., 2009. The silent mass extinction of insect herbivores in biodiversity hotspots. Conservation Biology 23, 1507-1515.

Gaspar, C., Borges, P.A.V., Gaston, K.J., 2008. Diversity and distribution of arthropods in native forests of the Azores archipelago. Arquipélago - Life and Marine Sciences 25, 1-30.

Gaspar, C., Gaston, K.J., Borges, P.A.V., Cardoso, P., in press. Selection of priority areas for arthropod conservation in the Azores archipelago. Journal of Insect Conservation. doi:10.1007/s10841-010-9365-4.

Gaston, K.J., 1994. Spatial patterns of species description: how is our knowledge of the global insect fauna growing? Biological Conservation 67, 37-40.

Gaston, K.J., May, R.M., 1992. Taxonomy of taxonomists. Nature 356, 281-282.

Gaston, K.J., Williams, P.H., 1993. Mapping the world's species - the higher taxon approach. Biodiversity Letters 1, 2-8.

González-Oreja, J.A., 2008. The encyclopedia of life vs. the brochure of life: exploring the relationships between the extinction of species and the inventory of life on Earth. Zootaxa 1965, 61-68.

Hernández, P.A., Graham, C.H., Master, L.L., Albert, D.L., 2006. The effect of sample size and species characteristics on performance of different species distribution modelling methods. Ecography 29, 773-785.

Hölldobler, B., Wilson, E.O., 1990. The Ants. Harvard University Press, Cambridge, Massachusetts.

Hortal, J., Lobo, J.M., Jiménez-Valverde, A., 2007. Limitations of biodiversity databases: case study on seed-plant diversity in Tenerife, Canary Islands. Conservation Biology 21, 853-863.

IUCN, 2010. IUCN Red List of Threatened Species. Version 2010.4. <http:// www.iucnredlist.org> (downloaded 01.04.11).

Jacobson, S.K., MacDuff, M.D., Monroc, M.C., 2007. Promoting conservation through the arts: outreach for hearts and minds. Conservation Biology 21, 7-10.

Janzen, D.H., 2004. Setting up tropical biodiversity for conservation through nondamaging use: participation by parataxonomists. Journal of Applied Ecology 41, 181-187.

Jones, D.T., Eggleton, P., 2000. Sampling termite assemblages in tropical forests: testing a rapid biodiversity assessment protocol. Journal of Applied Ecology 37. 191-203.

Kalkman, V.J., Boudot, J.-P., Bernard, R., Conze, K.-J., De Knijf, G., Dyatlova, E., Ferreira, S., Jovic, M., Ott, J., Riservato, E., Sahlén, G., 2010. European Red List of Dragonflies. Publications Office of the European Union, Luxembourg.

Kim, K.C., 1993. Biodiversity, conservation and inventory: why insects matter. Biodiversity and Conservation 2, 191-214.

Kozlowski, G., 2008. Is the global conservation status assessment of a threatened taxon a utopia? Biodiversity and Conservation 17, 445-448.

Kremen, C., Ostfeld, R.S., 2005. A call to ecologists: measuring, analyzing, and managing ecosystem services. Frontiers in Ecology and Environment 3, 540548

Kremen, C., Colwell, R.K., Erwin, T.L., Murphy, D.D., Noss, R.F., Sanjayan, M.A., 1993. Terrestrial arthropod assemblages: their use in conservation planning. Conservation Biology 7, 796-808.

Kremen, C., Williams, N.M., Thorp, R.W., 2002. Crop pollination from native bees at risk from agricultural intensification. Proceedings of the National Academy of Sciences of the USA 99, 16812-16816.

Labao, R., Francisco, H., Harder, D., Santos, F.I., 2008. Do colored photographs affect willingness to pay responses for endangered species conservation? Environmental and Resource Economics 40, 251-264.

Ladle, R.J., Jepson, P., 2008. Toward a biocultural theory of avoided extinction. Conservation Letters 1, 111-118.

Lawton, J.H., May, R.M., 1995. Extinction Rates. Oxford University Press, Oxford.

Leather, S.R., 2009. Institutional vertebratism threatens UK food security. Trends in Ecology and Evolution 24, 413-414.

Leather, S.R., Quicke, D.J.L., 2009. Where would Darwin have been without taxonomy? Journal of Biological Education 43, 51-52.

Lister, A.M., Brooks, S.J., Fenberg, P.B., Glover, A.G., James, K.E., Johnson, K.G., Michel, E., Okamura, B., Spencer, M., Stewart, J.R., Todd, J.A., Valsami-Jones, E., Young, J., 2011. Natural history collections as sources of long-term datasets. Trends in Ecology and Evolution 26, 153-154.
Landis, D.A., Wratten, S.D., Gurr, G.M., 2000. Habitat management to conserve natural enemies of arthropod pests in agriculture. Annual Review of Entomology 45, 175-201.

Lewis, O.T., Senior, M.J.M., 2011. Assessing conservation status and trends for the world's butterflies: the Sampled Red List Index approach. Journal of Insect Conservation 15, 121-128.

Lomolino, M.V., 2004. Conservation biogeography. In: Lomolino, M.V., Heaney, L.R. (Eds.), Frontiers of Biogeography: New Directions in the Geography of Nature. Sinauer Associates, Sunderland, Massachusetts, pp. 293-296.

Losey, J.E., Vaughan, M., 2006. The economic value of ecological services provided by insects. Bioscience 56, 311-323.

Mace, G.M., Collar, N.J., Gaston, K.J., Hilton-Taylor, C., Akçakaya, H.R., LeaderWilliams, N., Milner-Gulland, E.J., Stuart, S.N., 2008. Quantification of extinction risk: IUCN's system for classifying threatened species. Conservation Biology 22 1424-1442.

MacKinney, M.L., 1999. High rates of extinction and threat in poorly studied taxa. Conservation Biology 13, 1273-1281.

Margules, C.R., Pressey, R.L., 2000. Systematic conservation planning. Nature 405 243-253.

Martín, J.L., Cardoso, P., Arechavaleta, M., Borges, P.A.V., Faria, B.F., Abreu, C., Aguiar, A.F., Carvalho, J.A., Costa, A.C., Cunha, R.T., Fernandes, F.M., Gabriel, R., Jardim, R. Lobo, C., Martins, A.M.F., Oliveira, P., Rodrigues, P., Silva, L., Teixeira, D., Amorim, I.R., Homem, N., Martins, B., Martins, M., Mendonça, E., 2010. Using taxonomically unbiased criteria to prioritize resource allocation for oceanic island species conservation. Biodiversity and Conservation 19, 1659-1682.

Martín-López, B., Montes, C., Benayas, J., 2007. The non-economic motives behind the willingness to pay for biodiversity conservation. Biological Conservation 139, 67-82.

May, R.M., 1999. What we do and do not know about the diversity of life on earth In: Farina, A. (Ed.), Perspectives in Ecology. Backhuys Publisher, Leiden, pp. 3340.

Meuser, E., Harshaw, H.W., Mooers, A.O., 2009. Public preference for endemism over other conservation-related species attributes. Conservation Biology 23, 10411046.

Millennium Ecosystem Assessment, 2003. Ecosystems and Human Well-being: A Framework for Assessment. Island Press, Washington, DC.

Millennium Ecosystem Assessment, 2005. Ecosystems and Human Well-being: Synthesis. Island Press, Washington, DC.

Moberg, F., Folke, C., 1999. Ecological goods and services of coral reef ecosystems. Ecological Economics 29, 215-233.

Moir, M.L., Vesk, P.A., Brennan, K.E.C., Keith, D.A., Hughes, L., MacCarthy, M.A., 2010 Current constraints and future directions in estimating coextinction. Conservation Biology 24, 682-690.

Mokany, K., Ferrier, S., 2011. Predicting impacts of climate change on biodiversity: a role for semi-mechanistic community-level modelling. Diversity and Distributions 17, 374-380.

Muñoz, J., 2007. Biodiversity conservation including uncharismatic species Biodiversity and Conservation 16, 2233-2235.

Neves, R.C., Sørensen, K.J.K., Kristensen, R.M., Wanninger, A., 2009. Cycliophoran dwarf males break the rule: high complexity with low cell numbers. Biological Bulletin 217, 2-5.

New, T.R., 1999. Untangling the web: spiders and the challenges of invertebrate conservation. Journal of Insect Conservation 3, 251-256.

New, T.R., 2008. What's in common names: are they really valuable in insect conservation? Journal of Insect Conservation 12, 447-449.

New, T.R., 2010. Butterfly conservation in Australia: the importance of community participation. Journal of Insect Conservation 14, 305-311.

Novotny, V., Basset, Y., Miller, S.E., Weiblen, G.D., Bremer, B., Cizek, L., Drozd, P., 2002. Low host specificity of herbivorous insects in a tropical forest. Nature 416 , 841-844.

Pearson, D.L., Cassola, F., 1992. World-wide species richness patterns of tiger beetles (Coleoptera: Cicindelidae): indicator taxon for biodiversity and conservation studies. Conservation Biology 6, 376-391.

Pearson, D.L., Hamilton, A.L., Erwin, T.L., 2011. Recovery plan for the endangered taxonomy profession. Bioscience 61, 58-63.

Penev, L., Erwin, T.L., Thompson, F.C., Sues, H., Engel, M., Agosti, D., Pyle, R., Ivie, M., Assmann, T., Henry, T., Miller, J., Casale, A., Lourenço, W., Golovatch, S. Fagerholm, H., Taiti, S., Alonso-Zarazaga, M., 2008. ZooKeys, unlocking Earth's incredible biodiversity and building a sustainable bridge into the public domain: from "print-based" to "web-based" taxonomy, systematics, and natural history. ZooKeys 1, 1-6.

Penev, L., Hagedorn, G., Mietchen, D., Georgiev, T., Stoev, P., Sautter, G., Agosti, D. Plank, A., Balke, M., Hendrich, L., Erwin, T., 2011. Interlinking journal and wiki publications through joint citation: working examples from ZooKeys and Plazi on Species-ID. ZooKeys 90, 1-12.

Phillips, S.J., Anderson, R.P., Schapire, R.E., 2006. Maximum entropy modeling of species geographic distributions. Ecological Modelling 190, 231-259.

Pollard, E., Yates, T.J., 1993. Monitoring Butterflies for Ecology and Conservation. Chapman and Hall, London.

Prendergast, J.R., Quinn, R.M., Lawton, J.H., Eversham, B.C., Gibbons, D.W., 1993. Rare species, the coincidence of diversity hotspots and conservation strategies. Nature 365, 335-337.

Preston, F.W., 1948. The commonness, and rarity, of species. Ecology 29, 254-283.

Preston, F.W., 1960. Time and space and the variation of species. Ecology 41, 612627. 
Purvis, A., Hector, A., 2000. Getting the measure of biodiversity. Nature 405, 212219.

Rabinowitz, D., 1981. Seven forms of rarity. In: Synge, H. (Ed.), Aspects of Rare Plant Conservation. Wiley, New York, pp. 205-217.

Régnier, C., Fontaine, B., Bouchet, P., 2009. Not knowing, not recording, not listing: numerous unnoticed mollusk extinctions. Conservation Biology 23, 1214-1221.

Rodrigues, A.S.L., Pilgrim, J.D., Lamoreux, J.F., Hoffmann, M., Brooks, T.M., 2006. The value of the IUCN Red List for conservation. Trends in Ecology and Evolution 21, 71-76.

Roth, T., Weber, D., 2008. Top predators as indicators for species richness? Prey species are just as useful. Journal of Applied Ecology 45, 987-991.

Samways, M.J., 1993. Insects in biodiversity conservation: some perspectives and directives. Biodiversity and Conservation 2, 258-282.

Samways, M.J., 2005. Insect Diversity Conservation. Cambridge University Press, Cambridge.

Schuldt, A., Assmann, T., 2010. Invertebrate diversity and national responsibility for species conservation across Europe - a multi-taxon approach. Biological Conservation 143, 2747-2756.

Silverton, J., 2009. A new dawn for citizen science. Trends in Ecology and Evolution 24, 467-471.

Simberloff, D., 1998. Flagships, umbrellas, and keystones: is single-species management passé in the landscape era? Biological Conservation 83, 247-257.

Smith, F., May, R., Pellew, R., Johnson, T., Walter, K., 1993. How much do we know about the current extinction rate? Trends in Ecology and Evolution 8, 375-379.

Soberón, J., Nakamura, M., 2009. Niches and distributional areas: concepts methods, and assumptions. Proceedings of the National Academy of Sciences 106, 19644-19650.

Stork, N.E., Lyal, C.H.C., 1993. Extinction or 'co-extinction' rates. Nature 366, 307.

Stork, N.E., Samways, M.J., Eeley, H.A.C., 1996. Inventorying and monitoring biodiversity. Trends in Ecology and Evolution 11, 39-40.

Symondson, W.O.C., Sunderland, K.D., Greenstone, M.H., 2002. Can generalist predators be effective biocontrol agents? Annual Review of Entomology 47 561-594.

Thomas, J.A., Morris, M.G., 1994. Patterns, mechanisms and rates of extinction among invertebrates in the United Kingdom. Philosophical Transactions of the Royal Society of London B 344, 47-54.
Tisdell, C., Wilson, C., 2006. Information, wildlife valuation, conservation: experiments and policy. Contemporary Economic Policy 24, 144-159.

Triantis, K.A., Borges, P.A.V., Ladle, R.J., Hortal, J., Cardoso, P., Gaspar, C., Dinis, F., Mendonça, E., Silveira, L.M.A., Gabriel, R., Melo, C., Santos, A.M.C., Amorim, I.R., Ribeiro, S.P., Serrano, A.R.M., Quartau, J.A., Whittaker, R.J., 2010. Extinction debt on oceanic islands. Ecography 33, 285-294.

Van Swaay, C.A.M., Cuttelod, A., Collins, S., Maes, D., Munguira, M.L., Sasic, M., Settele, J., Verovnik, R., Verstrael, T., Warren, M.S., Wiemers, M., Wynhoff, I., 2010. European Red List of Butterflies. Publications Office of the European Union, Luxembourg.

Van Swaay, C., Maes, D., Collins, S., Munguira, M.L., Sasic, M., Settele, J., Verovnik, R., Warren, M., Wiemers, M., Wynhoff, I., Cuttelod, A., 2011. Applying IUCN criteria to invertebrates: how red is the Red List of European butterflies? Biological Conservation 144, 470-478.

Wheeler, Q.D., 2004. Taxonomic triage and the poverty of phylogeny. Philosophical Transactions of the Royal Society of London B 359, 571-583.

Wheeler, Q.D., 2007. Invertebrate systematics or spineless taxonomy? Zootaxa 1668, 11-18.

Wheeler, Q.D., Raven, P.H., Wilson, E.O., 2004. Taxonomy: impediment or expedient? Science 303, 285.

Williams, P.H., Araújo, M.B., 2000. Using probability of persistence to identify important areas for biodiversity conservation. Proceedings of the Royal Society of London B 267, 1959-1966.

Wilson, E.O., 1987. The little things that run the world (the importance and conservation of invertebrates). Conservation Biology 1, 344-346.

Wilson, E.O., 1992. The Diversity of Life. Belknap Press, Cambridge.

Wilson, E.O., 2000. On the future of conservation biology. Conservation Biology 14, $1-3$.

Wilson, E.O., 2003a. On global biodiversity estimates. Paleobiology 29, 14.

Wilson, E.O., 2003b. The encyclopedia of life. Trends in Ecology and Evolution 18, 77-80.

Wilson, C., Tisdell, C., 2005. What role does knowledge of wildlife play in providing support for species' conservation? Journal of Social Sciences 1, 47-51.

Zamin, T.J., Baillie, J.E.M., Miller, R.M., Rodríguez, J.P., Ardid, A., Collen, B., 2010. National red listing beyond the 2010 target. Conservation Biology 24, 10121020. 